\title{
Erratum: PARP1 promotes gene expression at the post-transcriptional level by modulating the RNA-binding protein HuR
}

Yueshuang Ke, Yanlong Han, Xiaolan Guo, Jitao Wen, Ke Wang, Xue Jiang, Xue Tian, Xueqing Ba, Istvan Boldogh \& Xianlu Zeng

Nature Communications 8:14632 doi: 10.1038/ncomms14632 (2017); Published 8 Mar 2017; Updated 31 Mar 2017

The original version of this Article contained an error in the spelling of post-transcriptional in the title of the paper. This has now been corrected in both the PDF and HTML versions of the Article.

(c) This work is licensed under a Creative Commons Attribution 4.0 International License. The images or other third party material in this article are included in the article's Creative Commons license, unless indicated otherwise in the credit line; if the material is not included under the Creative Commons license, users will need to obtain permission from the license holder to reproduce the material. To view a copy of this license, visit http://creativecommons.org/licenses/by/4.0/

(C) The Author(s) 2017 